\title{
Are Mammaglobin and GCDFP-15 Sensitive Markers for Diagnosis of Metastatic Basal-Like Triple Negative Breast Carcinomas?
}

\section{Mammaglobin ve GCDFP-15 Metastatik Üçlü Negatif Meme Kanserlerinin Tanısı İçin Duyarlı Belirleyiciler midir?}

\author{
Nasser RAKHSHANI, Arash DARYAKAR \\ Department of Pathology, Tehran University of Medical Sciences, Firuzgar Hospital, TEHRAN, IRAN ISLAMIC REPUBLIC
}

\begin{abstract}
Objective: There are small studies on expression of mammaglobin and GCDFP-15 for detection of basal-like triple negative breast cancer. This type of cancer has shorter survival and higher mortality rate. There must be reliable markers for detecting this type of tumor especially in metastatic cases with unknown origin.

Material and Method: In this study we assessed 66 paraffin blocks of breast cancers previously diagnosed as triple negative subtype in Mehr hospital (Tehran, Iran) by tissue microarray and immunohistochemistry technique for expression of mammaglobin and GCDFP-15.

Results: GCDFP-15 was positive in 12 cases (18.2\%) and the other $54(81.8 \%)$ cases remained negative. Mammaglobin was positive only in 6 cases (9.1\%) and the remaining 60 (90.9\%) cases were negative.

Conclusion: According to recent studies and our findings, there is no useful immunohistochemical marker for detection of breast source in cases of metastatic triple negative breast cancer with unknown origin and we must try hard to discover more accurate immunohistochemical markers for these highly metastatic breast cancers.
\end{abstract}

Key Words: Mammaglobin, Breast cancer, Immunohistochemistry, Differential diagnosis

\section{INTRODUCTION}

Breast cancers are believed to be among the most common cancers in women, and although diagnosis and treatment techniques have improved a lot, they are still considered as one of the main causes of death from cancers (1). DNA analysis of breast carcinoma has shown that there are distinct subtypes of breast carcinoma that were first found by Perou and his colleagues in 2000 (2).

(Turk Patoloji Derg 2014, 30:18-22)

Received : 31.05.2013 Accepted : 26.08.2013
ÖZ

Amaç: Üçlü negatif meme kanserlerinde mammaglobin ve GCDFP-15 varlığını saptama konusuyla ilgili az sayıda çalışma vardır. $\mathrm{Bu}$ tür kanserler kısa hasta sağ kalımı ve yüksek mortalite oranı gösterirler. Özellikle kökeni bilinmeyen metastatik kanser olarak ortaya çıktığında, bu tür kanserlere tanı koyabilmek için güvenilir belirleyicilere gereksinim vardır.

Gereç ve Yöntem: Bu çalışmada, daha önce İran, Tahran, Mehr Hastanesi'nde üçlü negatif kanser tanısı alan 66 hastanın parafin bloklarından, doku mikroarray bloklar hazırlanarak, immünhistokimyasal olarak mammaglobin ve GCDFP-15 antikorları kullanılarak değerlendirme yapıldı.

Bulgular: GCFPP-15, 12 olguda $(\% 18,2)$ pozitif bulunurken, kalan 54 hastada (\% 81,8) negatif bulundu. Mammaglobin 6 olguda $(\% 9,1)$ pozitif bulunurken, kalan 60 olgu $(\% 90,9)$ negatif bulundu.

Sonuç: Son zamanlarda yapılan çalışmalar ve bizim bulgularımız, kökeni bilinmeyen kanser olarak metastaz yaptığında, üçlü negatif meme kanserlerine, doğru tanı koymada faydalı olan immünhistokimyasal belirleyici bulunmadı̆̆ını göstermektedir. $\mathrm{Bu}$ konuda daha fazla çalışma yapılması gerekmektedir.

Anahtar Sözcükler: Mammaglobin, Meme kanseri, İmmünohistokimya, Ayırıcı tanı
Recently the subtypes of breast cancers recognized by their gene signature include luminal (type $\mathrm{A}$ and $\mathrm{B}$, and type C), HER2/neu type, basal-like, and normal breast-like. Attempts have been made to use immunohistochemistry (such as a panel including antibodies to estrogen receptor (ER), progesterone receptor (PR), HER2/neu, cytokeratin $5 / 6$, epidermal growth factor receptor (EGFR) and Ki67 to assign tumors to various molecular subtypes (3, 4). The "gold standard" to determine molecular invasive breast carcinoma (IBC) subtypes is gene expression array

Correspondence: Nasser RAKHSHANI

Pathology Ward, Mehr Hospital, Zartosht Street, TEHRAN, IRAN

E-mail: Kardaloria@gmail.com Phone: +0098 2188958785 
analysis, but this method requires fresh tissue. Surrogate immunohistochemical profiles correlating to the molecular subtypes have been developed (5).

Triple negative breast cancer (TNBC) is a subgroup of breast cancers that has been defined as negativity for ER, PR and Her2/neu markers by immunohistochemistry (IHC). It is also divided into 2 subgroups based on the expression of basal markers. These subgroups that are named basal-like and non-basal-like are positive and negative respectively for myoepithelial/basal markers such as cytokeratin 5/6, smooth muscle actin and EGFR (6).

A shorter survival course and higher metastatic rate are the characteristics of this type of breast cancer (7). Reliable markers should be found to identify this type of tumor especially in metastatic cases whose origins are unknown.

The basal-like subtype is characterized by the expression of myoepithelial / basal markers and molecular changes including TP53 gene mutations, BRCA1 inactivation, and many chromosomal alterations (8-10).

Gross cystic disease fluid protein 15 (GCDFP-15) was identified by Haagensen et al in 1977 (11). GCDFP is a $15-\mathrm{kDa}$ monomer found in chromosome 7 and cells with apocrine differentiation express it (12). Normal breast ducts and lobules do not represent GCDFP, although apocrine metaplastic epithelium expresses it An immunohistochemical study performed by Wick and colleagues in 1996, GCDFP-15 had a sensitivity and specificity up to $74 \%$ and $95 \%$, respectively, in primary mammary carcinoma (13). In another study by Fiel MI et al, GCDFP-15 was found to be positive in up to $57 \%$ of primary as well as metastatic breast carcinomas (14). Additionally Bhargava et al reported GCDFP-15 positivity in just about $25 \%$ of breast carcinomas (15).

Gene sequence of mammaglobin (MGB) was first discovered in breast carcinoma tissue in 1994 by Watson and Fleming (16). In 1996, they found complete DNA clone of MGB (17). In their study, MGB was positive in $50 \%$ of primary breast carcinomas and $62 \%$ of metastatic breast carcinomas. In the study of Han et al, sensitivity of mammaglobin antibody for the detection of breast cancer was $84.3 \%$ when compared with GCDFP-15 (44.3\%) in a series of 70 breast cancer cases (18).This marker is also imparted in benign breast epithelium. In this study we assessed paraffin blocks of breast cancers previously diagnosed as basal-like TNBC in Mehr Hospital (Tehran, Iran) using IHC technique for the expression of mammaglobin and GCDFP-15 markers.

At the time of writing this article only study of Lewis et al accessed sensitivity of mammaglobin and GCDFP-15 for detecting basal-like TNBC's that were $24 \%$ and $5 \%$, respectively (19). In attention to this fact that breast carcinoma is one of the most common metastatic cancers in women and TNBC's are highly metastatic, we want to assess sensitivity of GCDFP-15 and mammaglobin markers for diagnosis of these cancers. As in the work up of metastatic tumors with unknown origin when we consider a breast origin "unlikely" these two markers are immunohistochemically negative, can we do the same interpretation in TNBC's relying on these two markers?

\section{MATERIAL and METHODS}

In this cross sectional study, we collected 66 archived paraffin blocks previously diagnosed as primary basal-like TNBC in Mehr Hospital (Tehran, Iran). Immunohistochemical studies for ER, PR, HER2, cytokeratin $5 / 6$ and vimentin were previously performed on all cases between the years 2005 and 2012. All of these cases were sectioned in a fresh state and fixed overnight in 10\% neutral buffered formalin not longer than 24 hours. All tissue blocks were used by the patient's permission.

Tissue microarray: Tissue microarray (TMA) (Tissue arrayer Minicore, Alphelys, Plaisir, France) was made of 66 paraffin blocks of TNBC's. Three $1.4 \mathrm{~mm}$ tissue cores were obtained from tissue blocks on each case for increasing confidence coefficient. Each TMA contained 66 tissue cores, each $1.4 \mathrm{~mm}$ in diameter. These were arranged as 7 rows and 10 columns with 2 positive and negative controls beside them.

Immunohistochemical Analysis for Mammaglobin and GCDFP-15: Immunohistochemical studies for GCDFP and mammaglobin were performed on TMAs. Fourmicrometer-thick formalin-fixed, paraffin-embedded sections were immunostained with mammaglobin and GCDFP-15 antibodies (FLEX Monoclonal Mouse AntiHuman Mammaglobin Clone 3041A5, FLEX Monoclonal Mouse Anti-Human Gross Cystic Disease Fluid Protein-15, Clone 23A3, Ready-to-Use, DAKO, Glostrup, Denmark). The procedure was composed of pretreatment tissues using EnVision FLEX, Target Retrieval Solution, PH 8.0 followed by incubation with mammaglobin and GCDFP-15 mouse antibodies. Counterstaining in hematoxylin was used by EnVision FLEX Hematoxylin.

Positive and negative controls were run simultaneously using the same protocol as the patient specimens. For meaningful semiquantitative analysis, focal and/or weak staining was considered negative staining, and only patchy or diffuse staining with moderate or strong intensity was considered positive (15). 


\section{RESULTS}

Staining with the mammaglobin antibody was characteristically seen in the cytoplasm. The staining intensity in our series ranged from weak to moderate or strong. The number of cells stained with the antibody was further categorized as focal ( $<10 \%)$, patchy $(10 \%-50 \%)$, and diffuse $(>50 \%)$ (Table I).
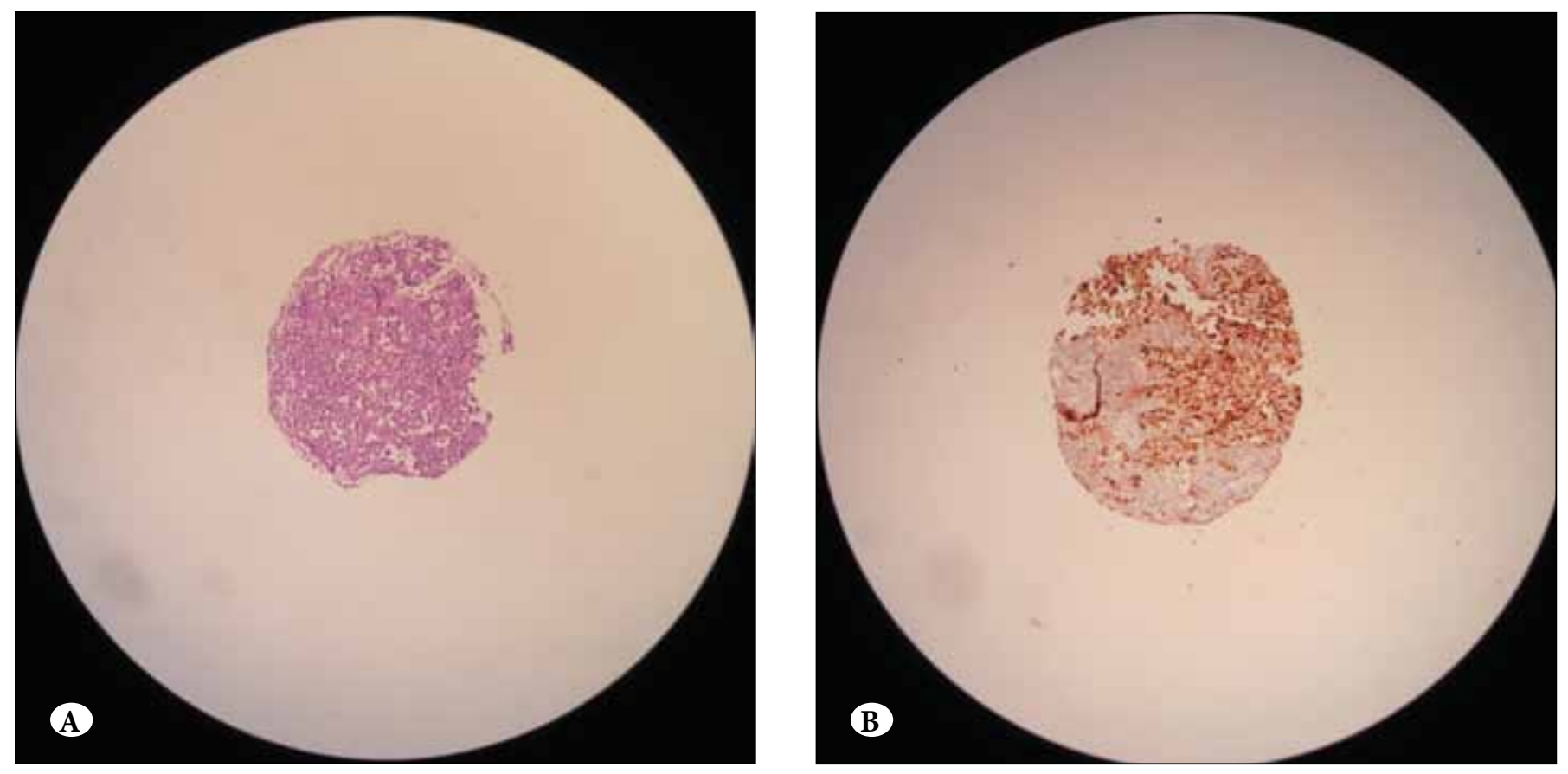

Figure 1: Basal-like triple negative breast carcinoma $(\mathbf{A}, \mathrm{H} \& \mathrm{E}, \times 400)$ showing strong staining with mammaglobin $(\mathbf{B}, \times 400)$.
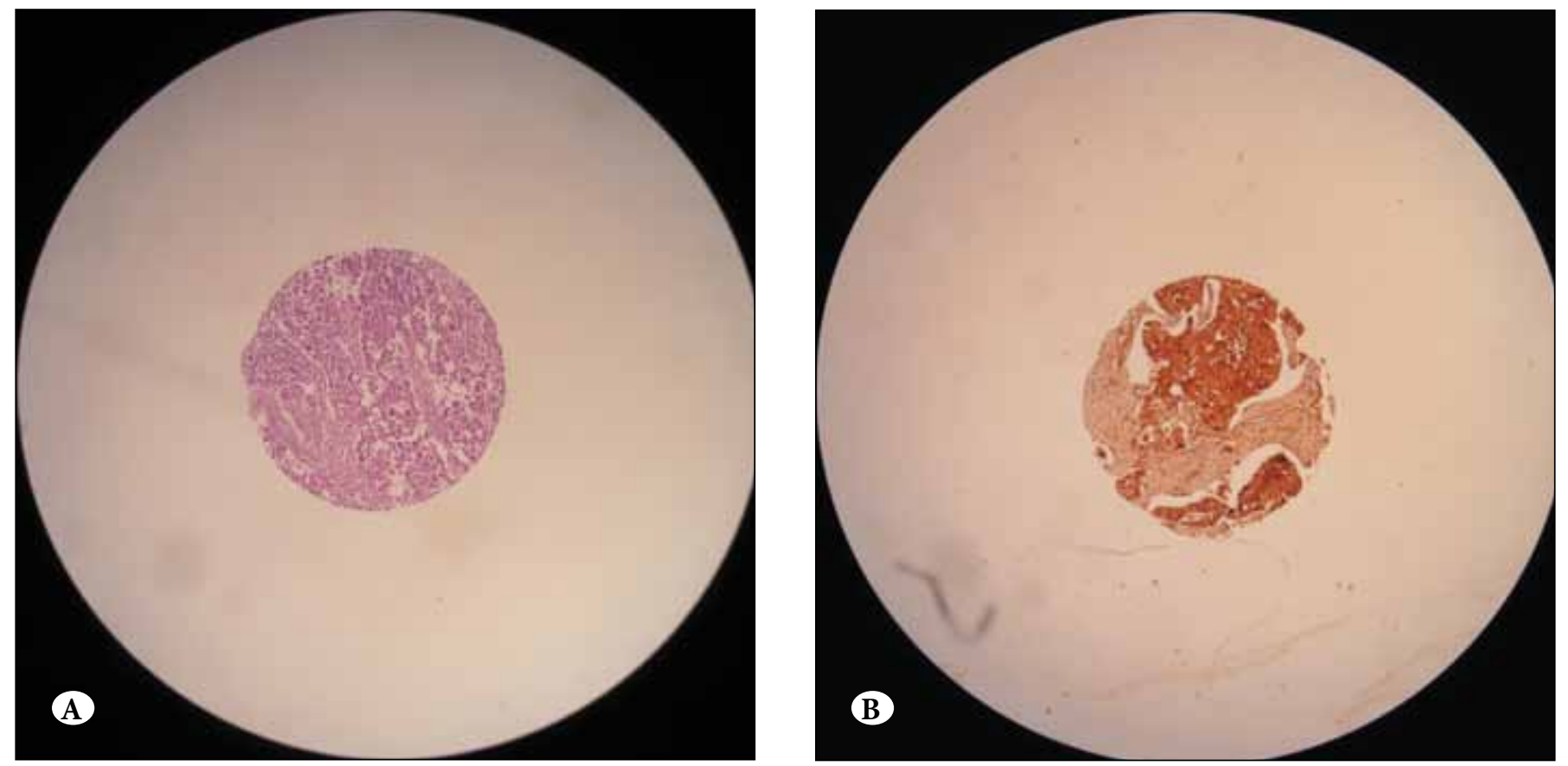

Figure 2: Basal-like triple negative breast carcinoma $(\mathbf{A}, \mathrm{H} \& \mathrm{E}, \times 400)$ showing strong staining with GCDFP-15 (B, $\times 400)$. 
Table I: Demographics of cases

\begin{tabular}{|lccccc|}
\hline \multicolumn{3}{|c|}{ Mammaglobin } & \multicolumn{3}{c|}{ GCDFP-15 } \\
\hline Pos. Neg. & Sens. $\%$ & Pos. & Neg & Sens. $\%$ \\
6 & 60 & 9.1 & 12 & 54 & 18.2 \\
\hline GCDFP-15, gross cystic disease fluid protein- 15. \\
* The Negative category includes focal and/or weak \\
staining, ie, focal weak, focal moderate, focal strong, \\
patchy weak, and diffuse weak staining. Focal implies \\
$<10 \%$ of cells positive; patchy is $10 \%-50 \%$; and diffuse \\
is $>50 \%$. \\
\hline
\end{tabular}

POS, positive; Neg, Negative; Sens, Sensitivity.

\section{DISCUSSION}

Breast cancer is the most common cancer in women in many countries of the world and is also the second cause of death due to cancers after lung cancer (20). TNBCs are subgroups of breast cancers identified by negativity for ER, PR and Her2/neu receptors. These cancers have a short survival and high metastatic rate (7). Although mammaglobin and GCDFP-15 have been discovered almost a decade ago, few studies have discussed their benefit for diagnosis of TNBCs.

Interestingly, mammaglobin is positive in few melanomas, and it is important to recognize this pitfall, for, it is unlikely to cause a problem in differential diagnosis from a breast carcinoma because a panel of immunohistochemical stains is always used in this matter. Mammaglobin does not seem to be a useful stain to distinguish breast from sweat gland carcinomas. Positive mammaglobin staining seen in salivary gland tumors was also expected; however, intense staining was not seen in any of the positive salivary gland tumors (15).

In Gloria $\mathrm{H}$. Lewis' study, the sensitivity of mammaglobin and GCDFP-15 IHC markers for detecting basal-like TNBCs has been $24 \%$ and $5 \%$, respectively. In our study, $9.1 \%$ and $18.2 \%$ of basal-like TNBC cases showed posistive immunohistochemical reaction for mammaglobin and GCDFP-15. Unlike Lewis et al's study, GCDFP-15 immunostaining was more frequent than mammaglobin immunostaining in our study.

Therefore, the false negative results of these markers for detecting TNBC's rated as $90.9 \%$ and $81.8 \%$ respectively. Hence, during pathological workup of a metastatic tumor with unknown origin by using these markers, the possibility of a TNBC entity will presumably missed. Since diagnosing a TNBC is a crucial factor in choosing a systemic treatment, postponing it can lead to a significant tumor progression.
TNBCs are highly aggressive with more intention to metastasize and shorter survival period. Our study revealed that 2 of the best IHC markers, used to detect the breast origin, have very low sensitivity. As these tumors metastasize to distant organs there is no useful IHC marker to detect the origin of the tumor. Therefore, it will be important for future studies to focus on finding accurate IHC markers for detection of this type of breast cancer and communicate closely with clinician and radiologist to correlate with clinical findings.

\section{ACKNOWLEDGMENTS}

We are grateful to pathology technicians of Tehran University of Medical Sciences and Mehr hospital for their assistance in processing and staining of the samples, Dr. Elham Mogharrablou and specially Beheshte Roudiany for her great assistance in the grammar of this article. The study was funded by Tehran University of Medical sciences, Tehran, Iran.

The authors declare that there is no conflict of interests.

\section{REFERENCES}

1. Hall JM, Lee MK, Newman B, Morrow JE, Anderson LA, Huey $B$, King MC. Linkage of early onset familial breast cancer to chromosome 17 q 21. Science. 1990; 250:1684-9.

2. He YD, Friend SH. Microarrays - the 21st century divining rod. Nat Med. 2001; 7:658-9.

3. Tang P, Skinner KA, Hicks DG. Molecular classification of breast carcinomas by immunohistochemical analysis: Are we ready? Diagn Mol Pathol. 2009; 18:125-32.

4. Tavassoli FA. Correlation between gene expression profilingbased molecular and morphologic classification of breast cancer. Int J SurgPathol. 2010; 18:167S-169S.

5. Nielsen TO, Hsu FD, Jensen K, Cheang M, Karaca G, Hu Z, Hernandez-Boussard T, Livasy C, Cowan D, Dressler L, Akslen LA, Ragaz J, Gown AM, Gilks CB, van de Rijn M, Perou CM. Immunohistochemical and clinical characterization of the basallike subtype of invasive breast carcinoma. Clin Cancer Res. 2004; 10:5367-74.

6. Burkhardt M, Mayordomo E, Winzer KJ, Fritzsche F, Gansukh T, Pahl S, Weichert W, Denkert C, Guski H, Dietel M, Kristiansen G. Cytoplasmic overexpression of ALCAM is prognostic of disease progression in breast cancer. J Clin Pathol. 2006; 59: 403-9.

7. Rakha EA, Reis-Filho JS, Ellis O. Basal-like breast cancer: A critical review. J Clin Oncol. 2008; 26:2568-81.

8. Da Silva L, Lakhani SR. Pathology of hereditary breast cancer Mod Pathol. 2010; 23 (Suppl 2):S46-S51.

9. Palacios J, Robles-Frias MJ, Castilla MA, Lopez-Garcia MA Benitez J. The molecular pathology of hereditary breast cancer. Pathobiology. 2008; 75:85-94.

10. Tan DS, Marchio C, Reis-Filho JS. Hereditary breast cancer: From molecular pathology to tailored therapies. J Clin Pathol. 2008; 61:1073-82. 
11. Haagensen DE Jr, Mazoujian G, Holder WD Jr, Kister SJ, Wells SA Jr. Evaluation of a breast cystic fluid protein detectable in the plasma of breast carcinoma patients. Ann Surg.1977; 185: 279-85.

12. Caputo E, Camarca A, Moharram R, Tornatore P, Thatcher B, Guardiola J, Martin BM. Structural study of GCDFP-15/gp17 in disease versus physiological conditions using a proteomic approach. Biochemistry. 2003; 42:6169-78.

13. Wick MR, Lillemoe TJ, Copland GT, Swanson PE, Manivel JC, Kiang DT. Gross cystic disease fluid protein-15 as a marker for breast cancer: Immunohistochemical analysis of 690 human neoplasms and comparison with alpha-lactalbumin. Hum Pathol. 1989; 20:281-7.

14. Fiel MI, Cernaianu G, Burstein DE, Batheja N. Value of GCDFP-15 (BRST-2) as a specific immunocytochemical marker for breast carcinoma in cytologic specimens. Acta Cytol. 1996; 40:637-41.

15. Bhargava R, Beriwal S, Dabbs DJ. Mammaglobin vs GCDFP-15. Am J ClinPathol. 2007; 127:103-13.
16. Watson MA, Fleming TP. Isolation of differentially expressed sequence tags from human breast cancer. Cancer Res.1994; 54:4598-602.

17. Watson MA, Fleming TP. Mammaglobin, a mammary specific member of the uteroglobin gene family, is overexpressed in human breast cancer. Cancer Res. 1996; 56:860-5.

18. Han JH, Kang Y, Shin HC, Kim HS, Kang YM, Kim YB, Oh SY. Mammaglobin expression in lymph nodes is an important marker of metastatic breast carcinoma. Arch Pathol Lab Med. 2003; 127:1330-4.

19. Lewis GH, Subhawong AP, Nassar H, Vang R, Illei PB, Park BH, Argani P. Relationship between molecular subtype of invasive breast carcinoma and expression of gross cystic disease fluid protein 15 and mammaglobin. Am J Clin Pathol. 2011; 135: 587-91.

20. Clarke RB. Anderson E, Howell A. Steroid receptors in human breast cancer. Trends Endocrinol Metab. 2004; 15: 316-23. 